\title{
Organizational flow chart of home care for children with special health care needs
}

\author{
Fluxograma organizativo de atenção domiciliar às crianças com necessidades especiais de saúde \\ Organigrama de atención domiciliaria a niños con necesidades de salud especiales
}

'Secretaria Municipal de Saúde. Cascavel, Paraná, Brazil.

"Universidade Estadual do Oeste do Paraná. Cascavel, Paraná, Brazil.

How to cite this article: Rossetto V, Toso BRGO, Rodrigues RM. Organizational flow chart of home care for children with special health care needs. Rev Bras Enferm. 2020;73(Suppl 4):e20190310. doi: http://dx.doi.org/10.1590/0034-7167-2019-0310

Corresponding author: Vanessa Rossetto E-mail:vanessa_rosseto@msn.com

EDITOR IN CHIEF: Antonio José de Almeida Filho ASSOCIATE EDITOR: Fátima Helena Espírito Santo

\begin{abstract}
Objective: To develop a workflow protocol for Home Care (HC) services in the $\mathrm{HC} 2$ modality for children with special health care needs (CSHCN) in the state of Parana. Method: Quantitative, descriptive, exploratory, multiple case studies. Data was collected with professionals from the eight home care services in Parana. Data were analyzed using the Strengths, Weaknesses, Opportunities and Threats (SWOT) methodology, from which a 5W2H method of action plan was developed, resulting in a flow chart. Results: Considering the strategies found in Home Care services, such as planned hospital discharge, caregiver training, organized transportation and singular therapeutic project, a flow organization protocol for children with special health care needs in Home Care services was developed. Conclusion: The protocol developed makes it possible to organize the care provided to children with special health care needs in home care. Descriptors: Child Health; Chronic Disease; Protocols; Homebound Persons; Pediatric Nursing.
\end{abstract}

\section{RESUMO}

Objetivo: Desenvolver protocolo de organização de fluxo nos serviços de atenção domiciliar (AD) para o cuidado na modalidade AD2a crianças com necessidades especiais de saúde (CRIANES), no estado do Paraná. Método: Pesquisa quantitativa, descritiva, exploratória, estudo de casos múltiplos. Coleta de dados com profissionais dos oito serviços de atenção domiciliar paranaenses. Os dados foram analisados com a metodologia Strengths, Weaknesses, Opportunities e Threats (SWOT), a partir da qual foi elaborado plano de ação pelo método $5 \mathrm{~W} 2 \mathrm{H}$, originando fluxograma normativo. Resultados: Considerando as estratégias encontradas nos serviços de atenção domiciliar, como alta hospitalar programada, preparo do cuidador, transporte sanitário organizado e projeto terapêutico singular, foi desenvolvido protocolo de organização de fluxo para crianças com necessidades especiais de saúde nos serviços de atenção domiciliar. Conclusão: O protocolo desenvolvido possibilita organizar o fluxo de atenção às crianças com necessidades especiais de saúde na atenção domiciliar.

Descritores: Saúde da Criança; Doença Crônica; Protocolos; Pacientes Domiciliares; Enfermagem Pediátrica.

\section{RESUMEN}

Objetivo: Desarrollar un protocolo de organigrama en los servicios de atención domiciliaria (AD) de la modalidad AD2 para niños con necesidades de salud especiales (CRIANES), en el estado de Paraná. Método: Se trata de una investigación cuantitativa, descriptiva, exploratoria, con estudio de casos múltiples. La recolección de datos se llevó a cabo con profesionales de los ocho servicios de atención domiciliaria paranaenses. Los datos se analizaron con la metodología DAFO (Debilidades, Amenazas, Fortalezas y Oportunidades), de la cual se elaboró el plan de acción con el método 5W2H que produjo el organigrama normativo. Resultados: Considerando las estrategias encontradas en los servicios de atención domiciliaria, como alta hospitalaria programada, preparación del cuidador, transporte sanitario organizado y proyecto terapéutico singular, se desarrolló el protocolo del organigrama para niños con necesidades de salud especiales en los servicios de atención domiciliaria. Conclusión: El protocolo desarrollado posibilita organizar el diagrama de flujo de atención a niños con necesidades especiales de saluden atención domiciliaria.

Descriptores: Salud del Niño; Enfermedad Crónica; Protocolos; Personas Imposibilitadas; Enfermería Pediátrica. 


\section{INTRODUCTION}

Technological development and qualification of health professionals have led to many advances in child health care in recent years in Brazil, resulting in increased survival rates of children and highlighting a group that requires special care from health services: Children with Special Health Care Needs (CSHCN), which include those with chronic diseases ${ }^{(1-2)}$.

Between nine and eleven percent of the total population of children and adolescents in Brazil have some type of chronic disease $^{(3)}$. For this reason, health care of these children must continue even after hospital discharge. With this in view, since 2011, Brazil has implemented the Melhor em Casa Program, in the context of Home Care $(\mathrm{HC})^{(4)}$.

$\mathrm{HC}$ is important for the care of individuals with chronic diseases, who require longitudinal care from a multidisciplinary team, which must offer comprehensive, continuous and humane care $^{(4)}$.However, a study has shown that the care network of these children, which has institutional and family care in its first dimension, was broad and diverse, but dispersed, with several different health and education professionals. This demonstrated the need for a better organization of services to achieve an effective care. The expansion and consolidation of multi-professional care is recommended to facilitate access to health care and improve the quality of life of these children and their families ${ }^{(5)}$.

A study with the objective of understanding the experience of mothers of technology-dependent children in relation to pharmaceutical care identified the need for reorganizing health services to provide comprehensive care, agile medication dispensing systems, and a network of professional support. Therefore, different services need to organize their workflow to provide efficient care for $\mathrm{CSHCN}^{(6)}$.

The reality in the United States of America was similar to our country, as shown in a study that explored the unmet health needs and health care utilization among youth with special health care needs. It found that differences in complexity of needs, race/ ethnicity, and poverty status highlight existing gaps in health care utilization and persistent unmet health needs among this population. Finally, it recommended that efforts should focus on strengthening coordinated systems of care that optimally meet the needs of this population ${ }^{(7)}$.

In this scenario, Brazil is one step ahead, as we have an organized care network, providing $\mathrm{HC}$ in three modalities: $\mathrm{HC}$, $\mathrm{HC} 2$ and $\mathrm{HC}$. In HC1, users are assisted by primary care teams, with home care provided according to their needs. In HC2 and $\mathrm{HC}$, care is provided by the Home Care Service (HCS), and the modality of care is defined according to the user's care needs, frequency of home visits (HV), intensity of multidisciplinary care and use of equipment ${ }^{(8)}$.

The HCS can be composed only of Multiprofessional Home Care Teams (MHCT), but can also have Multiprofessional Support Teams (MST) ${ }^{(8)}$.HC, due to its characteristics, can also be used for the care of CSHCN. However, no report of a protocol for the care of CSHCN in HC was found in Brazilian literature. Thus, considering this specific and permanent group and the growth in their life expectancy, the development of a protocol is necessary to guide the services and professionals involved.

\section{OBJECTIVE}

To develop a workflow protocol for Home Care $(\mathrm{HC})$ services in the $\mathrm{HC} 2$ modality for children with special health care needs (CSHCN)in the state of Parana, considering that most children in $\mathrm{HC}$ in Paraná are included in $\mathrm{HC2}$.

\section{METHODS}

\section{Ethical aspects}

All ethical precepts were followed, and the study was approved by the Research Ethics Committee of the State University of Western Paraná.

\section{Study design, setting and period}

A quantitative, descriptive, exploratory, multiple case studies was developed. The primary data for evaluating the care of CSHCN in HC in the state of Parana were obtained from a data collection in the eight HCS of Paraná, which are located in the cities of Cambé, Cascavel, Curitiba, Guarapuava, Londrina, Palotina, Paranavaí. and Santa Terezinha de Itaipu. The participants were professionals of these services and data was collected from August 2016 to January 2017.

These data were categorized according to the indications for the elaboration of service organization protocols ${ }^{(9)}$.Then, the analysis was performed using the SWOT method (Strengths, Weaknesses, Opportunities and Threats) ${ }^{(10)}$. Subsequently, the points listed were organized according to the $5 \mathrm{~W} 2 \mathrm{H}$ Action $\mathrm{Plan}^{(11)}$. In the last step, the results were represented graphically in a flow chart.

\section{Population, sample, inclusion and exclusion criteria}

The eight HCS in the previously mentioned cities of the state of Paraná were identified at the beginning of data collection. These services constituted the sample, and one professional from each service responded to the data collection instrument, with a total of eight participants.

The first contact was by a telephone call to the coordinators, who were invited to participate in the study. Those who could not participated indicated another professional from the service. Inclusion criteria was being an active member of the service. It was agreed upon that the data collection instrument would be sent by e-mail and returned by the participants by e-mail in a previously scheduled date. The data was confirmed by telephone after sending the e-mail.

\section{Study protocol}

Service organization protocols are tools used in the management of a service and cover the following categories: organization of work within a unit and within a territory; management flows in the proposal of the services network; evaluation processes; and construction of the information system, establishing the interfaces between the various units, between the levels of care and with other social institutions ${ }^{(9)}$.

The SWOT analysis (which stands for strengths, weakness, opportunities and threats) is a tool that provides support for 
management and planning of organizations ${ }^{(10)}$ and which is used in research in the area of health ${ }^{(11-13)}$.

Strengths are the qualities that differentiate an institution and represent an operational advantage in the environment. On the contrary, weaknesses are related to inappropriate situations, which give an institution an operational disadvantage in the environment. Strengths and weaknesses are classified as internal and controllable variables, while opportunities and threats are external and uncontrollable factors. Opportunities are the factors that can favor strategic action, while threats are situations that create obstacles to strategic action, but which, if recognized in a timely manner, can be avoided ${ }^{(10)}$.

The third tool used, the 5W2H Action Plan, is the elaboration of a structured strategy for the execution and control of tasks, assigning the responsibilities, the method, the reason, the costs and the deadlines for completion. Its development is based on the answers to the questions'what?'(what will be done?), 'who?' (who will do it?) 'when?' (when will it be done?),'where?' (where will it be done?), 'why?' (why will it be done?), 'how?'(how will it be done?) and'howmuch?' (how much will it cost?).These questions aim to define how actions will be developed to achieve the objectives ${ }^{(14)}$.

In the end, the results were graphically represented in a flow chart, with algorithms. This allows qualifying the representation and facilitates its understanding by the professionals who will use the results ${ }^{(9)}$.

Flow charts and algorithms can be used in protocols in order to organize and establish the flows of actions ${ }^{(9)}$. Algorithms are a finite sequence of instructions that can be mechanically executed over a period of time and with a finite amount of effort. They can be designed to repeat steps or indicate decisions until the task is completed ${ }^{(9)}$.

In the flow chart, each algorithm begins with an oval drawing, representing a population of patients with a defined characteristic, symptoms and complaints. These oval drawings are also called "clinical picture". The diamond shape represents clinical decision points, which have dichotomous outcomes (yes or no) and are decisive for the next steps, hence them being called decision points. The oval shape is used as an "exit", that is, it appears when a process reaches a conclusive stage, and no arrows start from this shape, as it is a closing figure. Rectangles represent specific groups of the care process in which diagnostic or therapeutic interventions should be performed ${ }^{(9)}$.

The symbols of the flow chart should be connected by arrows, with a single arrow leaving an oval shape or entering a hexagon or rectangle and two arrows leaving a hexagon (decision point), which indicate the answer "yes" when going right and "no" when going down ${ }^{(9)}$.

\section{Analysis of results}

The information obtained was categorized for description and comparison with the relevant literature. The variables are described in absolute and relative frequency, using the Excel software. These data supported the elaboration of the protocol presented.

\section{RESULTS}

\section{Categories for the elaboration of service organization protocols}

The results regarding aspects of the organization of work, its disposition in the territory, management flows for working within the network, evaluation processes and systems are presented in Chart 1.

Chart 1 - Listed aspects of the Home Care Service for the elaboration of protocols. 2017

\begin{tabular}{|c|c|}
\hline Favorable aspects & Unfavorable aspects \\
\hline \multicolumn{2}{|l|}{ Organization of work in the unit } \\
\hline $\begin{array}{l}\text { Presence of MHCT in most HCS; } \\
\text { Own telephone line; } \\
\text { HCS car available without prior arrangement; } \\
\text { Accountability of the caregivers, with a consent form; } \\
\text { Work developed in a multiprofessional team, with } \\
\text { exchange of experiences and construction of } \\
\text { strategies based on the perspectives of the different } \\
\text { professionals, aiming at a comprehensive approach. }\end{array}$ & $\begin{array}{l}\text { Working hours only on day shifts and not exceeding } 12 \text { hours on most HCS; } \\
\text { Telephone service carried out by professionals who are mostly unqualified to provide guidance; } \\
\text { Most transportations without monitoring from HCS professionals; } \\
\text { In the majority of hospitals, there is no training provided by MHCT professionals with a higher } \\
\text { education degree, and in the presence of hospital service staff; } \\
\text { Lack of standardization for caregiver training; } \\
\text { Lack of standardization of the HCS admission routine - reports made, use of forms, definition } \\
\text { of the professionals responsible for the admission, information in the term of responsibility, } \\
\text { therapeutic program, flow for contact with primary care, home medical records; } \\
\text { Lack of standardization of the first consultations, with definition of who performs the follow-up } \\
\text { and how often it occurs in the first weeks; } \\
\text { Low utilization of the Singular Therapeutic Program (STP). }\end{array}$ \\
\hline \multicolumn{2}{|l|}{ Organization of work in the territory } \\
\hline $\begin{array}{l}\text { Criteria for follow-up on } \mathrm{HC} 1, \mathrm{HC} 2 \text {, or } \mathrm{HC} 3 \text { are } \\
\text { established in an ordinance. }\end{array}$ & $\begin{array}{l}\text { There is no specific organization for the care of CSHCN in the territory; } \\
\text { Insufficient number of HCS in Parana. }\end{array}$ \\
\hline \multicolumn{2}{|l|}{ Management flows in the network } \\
\hline $\begin{array}{l}\text { Referral to the HCS not centered on the figure of the } \\
\text { physician, mostly; } \\
\text { Diverse and decentralized referral sources; } \\
\text { Formal moment of transfer of care for HC1 in some HCS; } \\
\text { Planned hospital discharge, mostly; } \\
\text { There is a national care network model for chronic } \\
\text { diseases. }\end{array}$ & $\begin{array}{l}\text { Lack of standardization of professionals who refer to HCS; } \\
\text { In the majority of hospitals, there is no training provided by MHCT professionals with a } \\
\text { higher education degree, and in the presence of hospital service staff } \\
\text { Inconstant communication between HCS and primary care in most of the services; } \\
\text { Discontinuation of follow-up in primary care of individuals followed in HCS in most cities; } \\
\text { Failure to agree on a specific flow for HCS with the emergency care network. }\end{array}$ \\
\hline
\end{tabular}




\begin{tabular}{|c|c|}
\hline \multicolumn{2}{|l|}{ Evaluation processes (for eligibility) } \\
\hline $\begin{array}{l}\text { Evaluation of eligibility not centered on the figure of } \\
\text { the physician in some HCS. }\end{array}$ & $\begin{array}{l}\text { Lack of standardization of professionals who assess eligibility; } \\
\text { Time limitation for eligibility assessment not standardized among HCS; } \\
\text { Lack of standardization of the factors included in the eligibility assessment (identification } \\
\text { of the caregiver, assessment of their ability to perform the necessary procedures at home, } \\
\text { acceptance of home care by the caregiver, in-home evaluation and organization of patient } \\
\text { transfer to home care); } \\
\text { Lack of standardization of caregiver skills assessment - understanding and execution of } \\
\text { procedures for eligibility and during follow-up. }\end{array}$ \\
\hline \multicolumn{2}{|l|}{ Information system } \\
\hline $\begin{array}{l}\text { National e-SUS information system available for use in } \\
\text { states and cities. }\end{array}$ & $\begin{array}{l}\text { Information systems do not communicate with other units; } \\
\text { Referral to home care depends on a time-consuming process; } \\
\text { Insufficient implementation of electronic and interconnected medical records. }\end{array}$ \\
\hline
\end{tabular}

Note: MHCT: Multiprofessional Home Care Teams; HCS: Home Care Service; CSHCN: Children with Special Health Care Needs.

Based on this, considering the positive points of the actions already developed in the services and the flaws that must be fixed, the main issues were pointed out and then organized according to the SWOT methodology.

\section{SWOT Analysis}

The SWOT analysis (Chart 2) considered the factors related to the organization of work in the unit and in the territory, the network flows, the evaluation processes and the information systems.

\section{W2H Action Plan}

The aspects listed were organized using the methodology of the $5 \mathrm{~W} 2 \mathrm{H}$ Action. In addition, based on the analysis of factors that favor and hinder the work process and on the guidelines for $\mathrm{HC}$, an action plan for the care of CSHCN in HC2 in Parana was developed, according to the following topics: (a) Planned hospital discharge; (b) Referral to HCS; (c) Eligibility assessment; (d) Caregiver training; (e) Transportation; (f) Admission script; (g) Singular Therapeutic Program; (h) Shared care; (i) Follow-up; (j)

Chart 2 - SWOT Analysis of Home Care Services in Parana, 2017

\begin{tabular}{|c|c|c|c|c|c|c|}
\hline \multirow{3}{*}{ 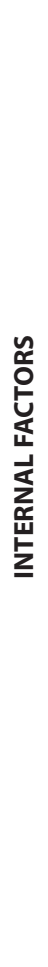 } & & $\begin{array}{l}\text { Organization of work } \\
\text { in the unit }\end{array}$ & $\begin{array}{c}\text { Organization of } \\
\text { work in the territory }\end{array}$ & $\begin{array}{l}\text { Management flows } \\
\text { in the network }\end{array}$ & Evaluation processes & $\begin{array}{l}\text { Information } \\
\text { Systems }\end{array}$ \\
\hline & 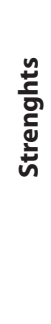 & $\begin{array}{l}\text { - Presence of MHCT in most } \\
\text { HCS. } \\
\text { - Owntelephoneline. } \\
\text { - HCS cars available without } \\
\text { prior arrangement. } \\
\text { - Accountability of the } \\
\text { caregivers, with a consent } \\
\text { form. } \\
\text { - Work developed in a } \\
\text { multiprofessional team. }\end{array}$ & $\begin{array}{l}\text { - Response time } \\
\text { when staff is } \\
\text { requested is not } \\
\text { standardized, } \\
\text { but is established } \\
\text { within teams and } \\
\text { is considered } \\
\text { appropriate. }\end{array}$ & $\begin{array}{l}\text { - Referral not centered on } \\
\text { the figure of the physician. } \\
\text { - Diverse and decentralized } \\
\text { referral sources. } \\
\text { - Formal meeting for the } \\
\text { transfer of care for HC1. } \\
\text { - Planned hospital } \\
\text { discharge. }\end{array}$ & $\begin{array}{l}\text { - Evaluation of } \\
\text { eligibility not } \\
\text { centered on the } \\
\text { figure of the } \\
\text { physician. }\end{array}$ & $\begin{array}{l}\text { - Existence of } \\
\text { computer } \\
\text { equipment. } \\
\text { - Existence of } \\
\text { internet network. }\end{array}$ \\
\hline & 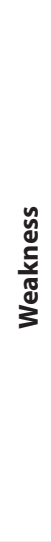 & $\begin{array}{l}\text { - Working hours only on day } \\
\text { shifts and not exceeding } 12 \\
\text { hours on most HCS. } \\
\text { - Telephone service carried } \\
\text { out by professionals who } \\
\text { are unqualified to provide } \\
\text { definitive guidance. } \\
\text { - Lack of standardization of the } \\
\text { admission routine. } \\
\text { - Lack of standardization of the } \\
\text { first consultations. } \\
\text { - Low utilization of the STP. } \\
\text { - Most transportations carried } \\
\text { out without monitoring from } \\
\text { HCS professionals. } \\
\text { - Lack of standardization for } \\
\text { caregiver training. }\end{array}$ & $\begin{array}{l}\text { - Insufficient } \\
\text { number of } \\
\text { HCS in Parana, } \\
\text { considering the } \\
\text { rates of child } \\
\text { morbidity. }\end{array}$ & $\begin{array}{l}\text { - Lack of standardization of } \\
\text { professionals who refer } \\
\text { to HCS. } \\
\text { - In the majority of hospitals, } \\
\text { there is no training } \\
\text { provided by MHCT } \\
\text { professionals with a higher } \\
\text { education degree, and in } \\
\text { the presence of hospital } \\
\text { service staff. }\end{array}$ & $\begin{array}{l}\text { - Time limitation for } \\
\text { eligibility assessment } \\
\text { not standardized } \\
\text { among HCS. } \\
\text { - Lack of } \\
\text { standardization } \\
\text { of caregiver skills } \\
\text { assessment. } \\
\text { - Lack of } \\
\text { standardization of } \\
\text { professionals who } \\
\text { assess eligibility. } \\
\text { - Lack of } \\
\text { standardization of the } \\
\text { factors included in the } \\
\text { eligibility assessment. }\end{array}$ & $\begin{array}{l}\text { - Information } \\
\text { systems do not } \\
\text { communicate } \\
\text { with other units. } \\
\text { - Information } \\
\text { system focused } \\
\text { on the production } \\
\text { of productivity } \\
\text { data. }\end{array}$ \\
\hline 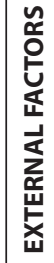 & 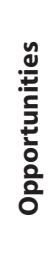 & $\begin{array}{l}\text { Possibility of requesting } \\
\text { MHCT in the HCS that do } \\
\text { not have it yet. }\end{array}$ & $\begin{array}{l}\text { - Criteria for } \\
\text { follow-up on } \mathrm{HC} 1 \text {, } \\
\text { HC2, or HC3 are } \\
\text { established in an } \\
\text { ordinance. }\end{array}$ & $\begin{array}{l}\text { - National care network for } \\
\text { chronic diseases. }\end{array}$ & $\begin{array}{l}\text { - Participation in } \\
\text { evaluative research } \\
\text { and possibility of } \\
\text { reflection on the } \\
\text { results for changes in } \\
\text { care practice }\end{array}$ & $\begin{array}{l}\text { - Existence of } \\
\text { an information } \\
\text { system, the e-SUS } \\
\text { HC, which can } \\
\text { be adapted for } \\
\text { communication. }\end{array}$ \\
\hline
\end{tabular}




\begin{tabular}{|c|c|c|c|c|c|c|}
\hline \multirow[b]{2}{*}{ 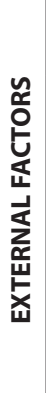 } & \multirow[b]{2}{*}{ 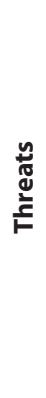 } & $\begin{array}{c}\text { Organization of work } \\
\text { in the unit }\end{array}$ & $\begin{array}{c}\text { Organization of } \\
\text { work in the territory }\end{array}$ & $\begin{array}{l}\text { Management flows } \\
\text { in the network }\end{array}$ & Evaluation processes & $\begin{array}{l}\text { Information } \\
\text { Systems }\end{array}$ \\
\hline & & $\begin{array}{l}\text { - The way care is organized } \\
\text { is different in each HCS } \\
\text { surveyed, denoting the } \\
\text { absence of care protocols. }\end{array}$ & $\begin{array}{l}\text { - Lack of flow of } \\
\text { care for CSHCN in } \\
\text { the territory. }\end{array}$ & $\begin{array}{l}\text { - Inconstant communication } \\
\text { between HCS and the } \\
\text { health care network. } \\
\text { - Discontinuation of follow- } \\
\text { up in primary care of } \\
\text { individuals followed in HCS. } \\
\text { - Failure to agree on a } \\
\text { specific flow for HCS } \\
\text { with the emergency care } \\
\text { network. }\end{array}$ & $\begin{array}{l}\text { - Lack of self- } \\
\text { assessment or even } \\
\text { formal assessment } \\
\text { from the State } \\
\text { in relation to the } \\
\text { services provided. }\end{array}$ & $\begin{array}{l}\text { - Referral to home } \\
\text { care depends on a } \\
\text { time-consuming } \\
\text { process. } \\
\text { - Insufficient } \\
\text { implementation } \\
\text { of electronic and } \\
\text { interconnected } \\
\text { medical records. }\end{array}$ \\
\hline
\end{tabular}

Note: MHCT: Multiprofessional Home Care Teams; HCS: Home Care Service; CSHCN: Children with Special Health Care Needs; STP: Singular Therapeutic Program.

Telephone guidance; (k) Electronic and interconnected medical records; and (I) Specific flow in the emergency network. Cost analysis was not applied at this stage.

a) Hospital discharge planned by the hospital staff; when a child with special health care needs who will be discharged meets criteria for follow-up in $\mathrm{HC2}$, refer the child to HCS.

b) Referral to HCS done by nurses, physicians, physical therapists and social workers from hospitals (public or private) when CSHCN meet the criteria for follow-up in $\mathrm{HC2}$, using their own form, by e-mail or electronic medical record.

c) Eligibility assessment in hospitals (public or private), done by MHCT professionals with higher education, within one to seven days after receiving the referral. It includes the identification of the caregiver, the evaluation of their ability to perform the necessary procedures at home and their acceptance of home care.

d) Training of the caregiver conducted by MHCT professionals and hospital professionals with higher education degrees, after patients is considered eligible for $\mathrm{HC2}$, including guidance and demonstrations to instruct the caregiver in relation to the care that will be required at home.

e) Transportation from hospital to home (when the caregiver is already trained), with a patient transport vehicle from the HCS or from the city hall, according to the established flow. Transportation with monitoring of an HCS nursing technician and with a kit of materials for home care. This flow aims to convey safety to parents who are leaving the hospital and assuming home care, as the transition will occur with the service professional who will continue the follow-up.

f) Admission script. After transfer to home care, MHCT professionals with higher education are responsible for admission to HCS, reinforcing care guidelines with the support of printed materials, and explaining HCS care, providing telephone contact and reading the Term of Responsibility of the Caregiver, in which the caregiver assumes the responsibility of performing the care as guided by the HCS team.

g) Singular Therapeutic Program developed by the MHCT along with the caregiver, in the first HV after admission (within one week), addressing diagnosis, goal setting, division of responsibilities and tasks, and re-evaluation planning. Evaluation and implementation of actions by MST professionals within the same week, upon request by the MHCT and according to the needs identified in the STP. h) Shared care. Communicate the primary care referral unit on the admission to HCS and send the case report and the STP monthly, via electronic medical record or e-mail, requesting the unit's contribution in the division of responsibilities and the continuity of follow-up in primary care for patients in $\mathrm{HCS}$.At the time of transfer of care to $\mathrm{HC} 1$, hold a meeting with the MHCT and the staff of the primary care referral unit in the health unit.

i) Follow-up with HVs at least once a week, according to the team's schedule or at the request of the family caregiver, with a car that is available in the HCS. The follow-up includes observation of the performance of care, evaluation of the child's evolution and orientation on new care, if necessary. The professionals must identify needs for professional support in the family and provide it within the network.

j) Telephone guidance performed by qualified professional or someone in contact with MHCT on mobile phone. Guidance is for clarifying doubts or for cases of destabilization of the child, without emergency. If necessary, a re-evaluation is provided by MHCT or MST.

k) Electronic medical record interconnecting the HCS, the primary care units and other parts of the health care network for the registration and exchange of pertinent referral information.

I) Specific flow in the emergency network, where the Mobile Emergency Service (SAMU) provides urgent and emergency care, with home or hospital outcome, and support when there is no care in the HCS.

\section{Graphic representation}

Figure 1 presents the flow chart for $\mathrm{CSHCN}$ in $\mathrm{HC} 2$, developed based on the successful experiences pointed out by the participants. The flow chart is in the phase of clinical validation in the services participating in the study.

\section{DISCUSSION}

The strategic plan developed from the SWOT analysis made it possible to evaluate each sphere involved in the organization of work in the service and in its context. In a study ${ }^{(13)}$ on solid waste management, conducted in a city in the state of São Paulo, Brazil, this method of analysis also contributed to the understanding of the problem. 


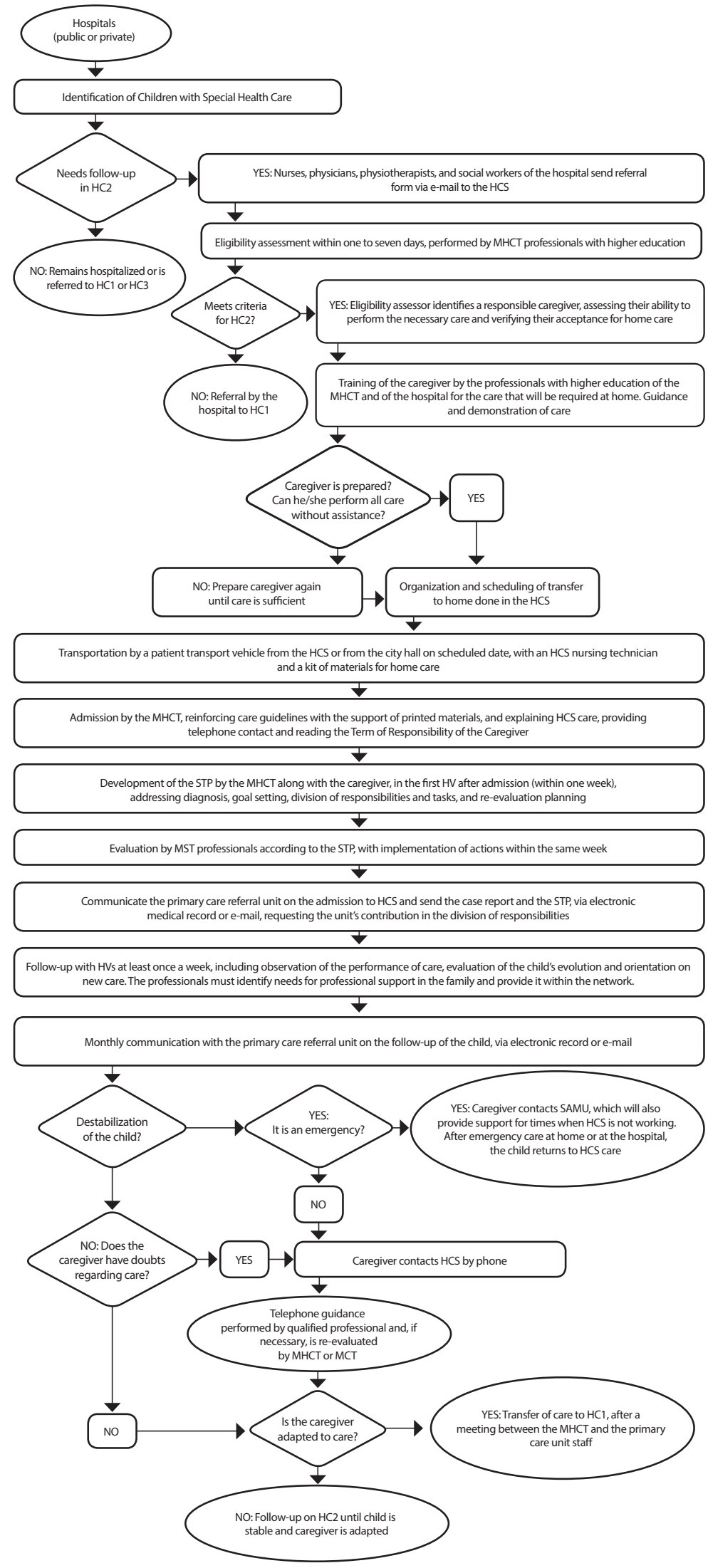

Note: HC2: Home Care modalitie 2; HC1: Home Care modalitie 1; HC3: Home Care modalitie 3; HCS: Home Care Service; MHCT: Multiprofessional Home Care Teams; STP: Singular Therapeutic Program; MST: Multiprofessional Support Teams; HV: Home Visit; SAMU: Mobile Emergency Service.

Figure 1 - Flow chart for Children with Special Health Care Needs in HC2
The work is organized in the unit according to the reality of the territory. The work organization aims to create answers that can modify reality, acting on the determinants and producing health by generating knowledge, feeding the information system and connecting institutions in the health sector or outside it ${ }^{(9)}$.

Thus, for the organization of work in the territory, services should use protocols that best meet the needs identified in their territories ${ }^{(9)}$.

Territorialization can be described as the process of appropriation of space by Primary Health Care (PHC) services. In other words, it is the process of establishing territories covered by PHC units, aiming to clearly define the areas of work of primary care services ${ }^{(15)}$. This concept can be extended to home care. The insufficient number of HCS in the state may affect the number of hospitalizations of children, which in 2015 and 2016 corresponded to 84,787 and 88,667, meaning that about $10.9 \%$ of hospitalizations in Parana were of children up to ten years old ${ }^{(16)}$.

Management flows refer to the definition of referral and counter-referral actions among services, in order to facilitate access, longitudinally and continuity of care $^{(9)}$. As PHC is the level of health care that is the closest to users of the Unified Health System (SUS) and its actions are developed in the Basic Health Units (BHU), it represents the entrance way and the communication center with all the healthcare network ${ }^{(17)}$ Therefore, it is responsible for the referral from PHC to the other levels of care, while in the counter-referral, the user returns from the other levels of care to $\mathrm{PHC}^{(17)}$.

In realities in which referral and counter-referral systems occur through precarious and bureaucratic flows, the possibilities of coordination between levels of care are obstructured ${ }^{(18)}$.

The analysis of the evaluation processes is related to monitoring and judging an intervention, with the objective of making an analysis of the action implemented and assisting decision making, leading a new path ${ }^{(19)}$.

Information systems have the purpose of selecting data that is relevant to services and transforming it into information necessary for decision-making processes. They are a mechanism for collecting, processing, analyzing and transmitting the information necessary to plan, organize, operate and evaluate health services ${ }^{(20)}$.

In this sense, the e-SUS Primary Care (e-SUS PC) was developed as a strategy of the Department of Primary Care (DAB), of the Ministry of Health, aimed at restructuring the information of $\mathrm{PC}$ at national level and qualifying information management; in order to increase the quality of the service delivered to the population ${ }^{(21)}$. 
In 2015, a version of e-SUS PC was launched in the e-SUS HC module as an information system for HCS to record MHCT and MST production information, with the objective of qualifying the information used for monitoring and planning of HCS(21). For information systems to be efficient, they must be interconnected with other health network services. However, this system does not fulfil the function of enabling communication between health care units.

Seeing that the factors that hinder the work process outnumbered those that favor it, it is essential to adopt an action plan that enhances the strengths of the HCS, so that they favor the work and overshadow the harmful factors. In the SWOT analysis, the factors were divided into the categories strengths, weaknesses, opportunities and threats, allowing reflection and enabling the elaboration of the action plan, based on the intersection of the information, as in studies using the same methodology ${ }^{(10-13)}$.

An efficient action plan should clearly address all aspects involved in the process, such as the professionals responsible for each action, the deadlines, time and place and what will be considered at each step ${ }^{(11)}$. Thus, all aspects pointed out in the action plan, such as planned hospital discharge, referral to HCS, eligibility assessment, caregiver training, transportation, admission script, singular therapeutic project, shared care, follow-up, telephone guidance, electronic and interconnected medical records, and specific flow in the emergency network were contemplated and represented step by step in the flow chart, as in a study ${ }^{(22)}$ that elaborated a flow chart for care in a psychosocial care center.

\section{Limitations of the study}

A limitation of this study is the fact that, although the CSHCN care flow instrument in $\mathrm{HC} 2$ was built considering the reality of services and $\mathrm{HC}$ guidelines, it is still being tested by the services. Therefore, future studies should evaluate its practical application in services.

\section{Contributions to Nursing and HC Public Policy}

The elaboration of this protocol provides support for strengthening $\mathrm{HC}$ in Parana, by providing care for $\mathrm{CSHCN}$, equipping the professionals involved, enhancing the available resources and organizing the work process. For the nurse, who works in all dimensions of $\mathrm{HC}$, from organization to assistance, this protocol can help managing patients in their flow from hospital to home care.

\section{CONCLUSION}

The study presented an organizational flow chart for CSHCN, prepared by nurses for $\mathrm{HC}$ in the state of Parana, based on a methodology derived from organizational management. This has contributed to the production of health management technologies.

\section{REFERENCES}

1. Cabral IE, Moraes JRMM. Family caregivers articulating the social network of a child with special health care needs. Rev Bras Enferm [Internet]. 2015 [cited 2016 Jun 10];68(6):769-76. Available from: http://www.scielo.br/pdf/reben/v68n6/en_0034-7167-reben-68-06-1078.pdf

2. McPherson MG, Arango P, Fox H, Lauver C, McManus M, Newacheck PW, et al. A new definition of children with special health care needs. Pediatrics [Internet]. 1998 [cited 2016 Jul 02];102:137-41. Available from: https://pdf.semanticdholar.org/6e8f/1de37e17e37af6dc4ddf769ea 80ebf03c44.pdf

3. Instituto Brasileiro de Geografia e Estatística. Pesquisa Nacional por Amostra de Domicílios: um panorama da saúde no Brasil, acesso e utilização dos serviços, condições de saúde e fatores de risco e proteção à saúde. Rio de Janeiro (RJ): Fiocruz/MS/IBGE; 2010.

4. Oliveira Neto AVO, Dias MB. Atenção domiciliar no Sistema Único de Saúde (SUS): o que representou o Programa Melhor em Casa? Divulg Saúde Debate[Internet]. 2014 [cited 2016 Jun 11]51:58-71. Available from: cebes.org.bbr/site/wp-content/uploads/2014/12/Divulgação-51.pdf

5. Neves ET, Silveira A, Arrué AM, Pieszak GM, Zamberlan KC, Santos RP. Rede de cuidados de crianças com necessidades especiais de saúde. Texto Contexto Enferm. 2015;24(2):399-406. doi: 10.1590/0104-07072015003010013

6. Okido ACC, Cunha ST, Neves ET, Dupas G, Lima RAG. Technology-dependent children and the demand for pharmaceutical care. Rev Bras Enferm. 2016;69(4):671-7. doi: 10.1590/0034-7167.2016690415i

7. Parasuraman SR, Anglin TM, McLellan SE, Riley C,Mann MY. Health care utilization and unmet need among youth with special health care needs. J Adolescent Health. 2018;63(4):435-44. doi: 10.1016/j.jadohealth.2018.03.020

8. Ministério da Saúde (BR). Portaria no 825 de 2016, Redefine a Atenção Domiciliar no âmbito do Sistema Único de Saúde (SUS) e atualiza as equipes habilitadas. Brasília: MS; 2016.

9. Werneck MAF, Faria HP, Campos KFC. Protocolo de cuidados à saúde e de organização de serviço. Belo Horizonte: Nescon/UFMG, Coopmed; 2009.

10. Navarro FAR, Alencar C. Analysis of the strategic elements in internationalization processes: Brazilian real estate companies targeting the residential market of Costa Rica. Ambient Constr [Internet]. 2016 [cited 2017 Oct 03]16(1):285-99. Available from: http://www.scielo.br/pdf/ ac/v16n1/1678-8621-ac-16-01-0285.pdf

11. Esteves SC, Agarwal A, Cho C, Majzoub A. A Strengths-Weaknesses-Opportunities-Threats (SWOT) analysis on the clinical utility of sperm DNA fragmentation testing in specific male infertility scenarios. Translat Androl Urol[Internet]. 2017 [cited 2017 Feb 06]6(4):734-60. Available from: https://www.ncbi.nlm.nih.gov/pubmed/29082207

12. Kawai T. The historicity and potential of Jungian analysis: another view of 'SWOT'. J Analytic Psychol [Internet]. 2017 [cited 2017 Jan 25]62(5):629-798. Available from: https://www.ncbi.nlm.nih.gov/pubmed/28994468 
13. Assis MC, Gomes VAP, Balista WC, Freitas RR. Use of performance indicators to assess the solid waste management of health services. An Acad Bras Ciênc. 2017;89(3):2445-60. doi: 10.1590/0001-3765201720170178

14. Machado BSB, Viegas MC. Estudo de Caso: As ferramentas da qualidade utilizadas no laboratório de análises clínicas de um hospital para a otimização de processos. UNOPAR Cient, Ciênc Juríd Empres [Internet]. 2012 [cited 2017 Apr 18]13(1):75-80. Available from: pgsskroton. com.br/seer/índex.php/jurídicas/article/viewFile/825/791

15. Caires ES, Santos Jr PJ. Territorialization in health: a reflection on their importance in primary attention. Rev Eletrôn Acervo Saúde [Internet]. 2017 [cited 2017 Oct 20]9(1):1174-7. Available from: https://www.acervosaude.com.br/doc/REAS2.pdf

16. Ministério da Saúde (BR). Sistema de Informações Hospitalares do SUS (SIH/SUS). Morbidade hospitalar [Internet]. 2017 [cited 2008 Feb 15]. Available from: http://tabnet.datasus.gov.br/cgi/tabcgi.exe?sih/cnv/nipr.def

17. Pereira JS, Machado WCA. Reference and counter-reference between physical rehabilitation services of Persons with Disabilities: (dis) articulation in the Fluminense Central-South region, Rio de Janeiro, Brazil. Physis[Internet]. 2016 [cited 2017 Nov 04]26(3):1033-1051. Available from: http://www.scielo.br/pdf/physis/v26n3/0103-7331-physis-26-03-01033.pdf

18. Santos AM, Giovanella L. Gestão do cuidado integral: estudo de caso em região de saúde da Bahia, Brasil. Cad Saúde Pública. 2016;32(3). doi: 10.1590/0102-311X00172214

19. Dalfior ET, Lima RCD, Andrade MAC. Reflections on implementation analysis of health policies. Saúde Debate [Internet]. 2015 [cited 2017 Feb 17]39(104):210-25. Available from: https://www.scielosp.org/pdf/sdeb/2015.v39n104/210-225/pt

20. Guimarães EMP, Évora YDM. Sistema de informação: instrumento para tomada de decisão no exercício da gerência. Ciên Inform [Internet]. 2004[cited 2017 Nov 13]33(1):72-80. Available from: revista.ibict.br/ciinf/article/view/1070/1163

21. Ministério da Saúde (BR). Portal da Saúde. E-sus atenção básica [Internet]. 2017[cited 2017 Nov 21]. Available from: http://dab.saude.gov.br/ portaldab/esus.php

22. Aquino MST, Souza PH, Dutra FCS, Vasconcelos PF. Implantação de fluxograma de atendimento em um centro de atenção psicossocial. Rev Bras Promoç Saúde [Internet]. 2017 [cited 2017 Oct 28]30(2):288-93. Available from: www.redalyc.org/408/40851821018.pdf 